\title{
History of Education
}

Quarterly

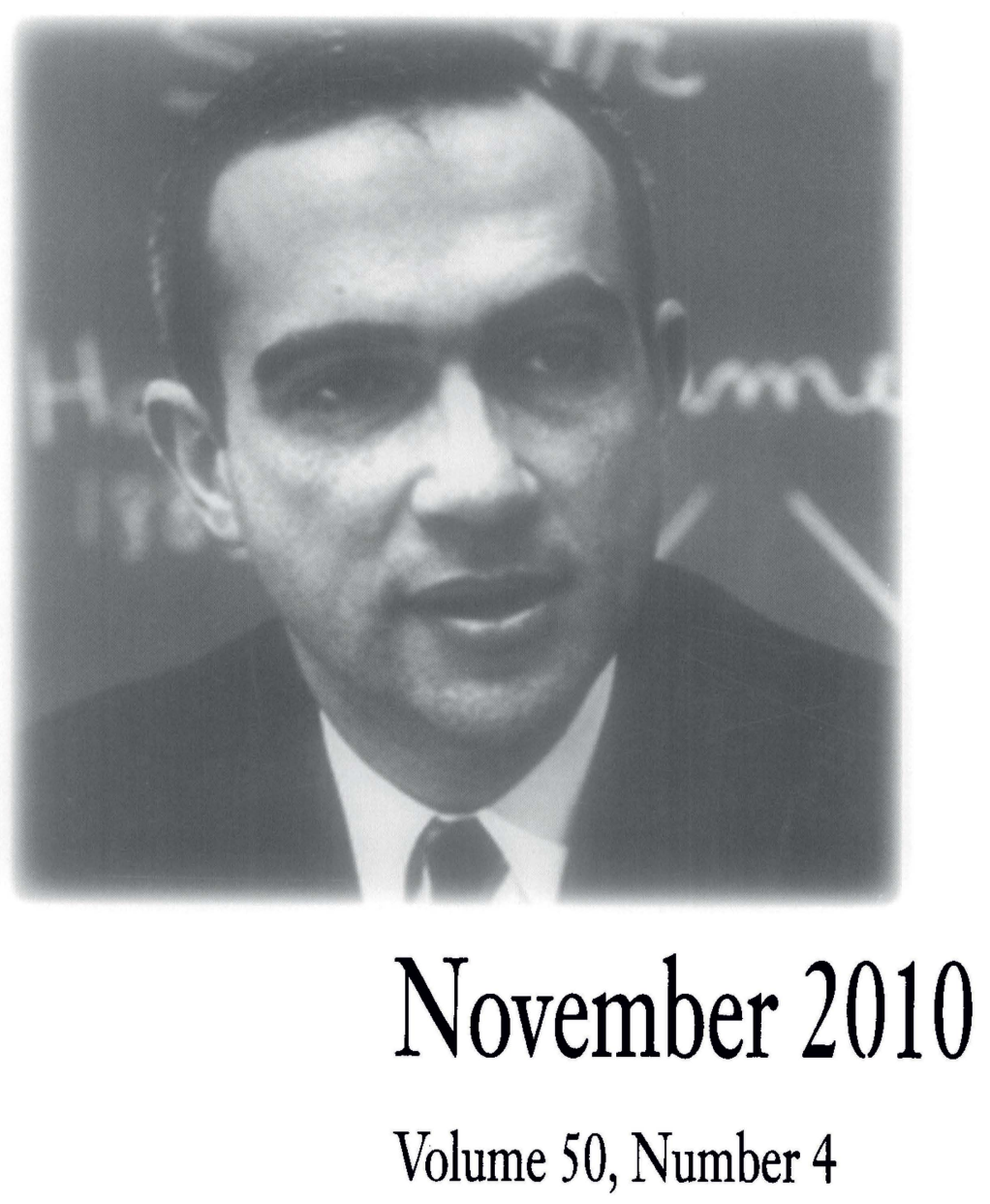


THE HISTORY OF EDUCATION BEST ARTICLE AWARD: The History of Education Society awards a prize of $\$ 750$ biennially for the best article in the history of education, broadly defined to cover a wide range of educational and cultural issues inside and outside of the United States. This includes work on schools and universities, teachers, students, and families. The next award will be presented at the fall 2010 meeting of the History of Education Society. Articles published in journals during 2008 and 2009 (no book chapters) are eligible. Self-nominations are welcome.

Entrants should send five hard copies of the article or a PDF version via email to:

Milton Gaither

Dept. of Education Box 3019

Messiah College

Grantham, PA 17027

Email:MGaither@messiah.edu

2010 CLAUDE A. EGGERTSEN DISSERTATION PRIZE HISTORY OF EDUCATION SOCIETY: The History of Education Society is accepting submissions for the Claude A. Eggertsen Prize for the dissertation judged to be most outstanding in the field of History of Education. This includes work on schooling and educational institutions more broadly, and the dissertation may have a domestic or international focus. The next award will be presented at the 2010 meeting of the History of Education Society. The prize carries an award of $\$ 1,000$ for the winner. Self-nominations are welcome. Qualified applicants must have completed the dissertation and graduated during the calendar year 2009. Entrants should send one copy of the complete dissertation to each of the three prize committee members:

Margaret A. Nash (chair)

Graduate School of Education

900 University Avenue

Sproul Hall 1207

Riverside, CA 92521-0128

Valinda W. Littlefield

Department of History

Gambrell Hall 237

University of South Carolina

Columbia, SC 29208

Brian M. Puaca

Department of History

Christopher Newport University

1 University Place

Newport News, VA 23606

If you have questions or need more information, write to Margaret A. Nash at Margaret.nash@ucr.edu For further announcements and deadlines please refer to the History of Education website: http://www.historyofeducation.org/.

2010 THE LINDA EISENMANN PRIZE: The History of Education Society is pleased to announce the creation of the Linda Eisenmann Prize for Distinguished Scholarship by a Junior Scholar in the Field of the History of Higher Education in the United States. The first award will be presented at the HES Annual Meeting in November, 2010.

The Prize Committee (Marybeth Gasman, Roger Geiger, and Bruce Leslie) solicits nominations for works that fulfill the following criteria:

Subject: The History of Higher Education in the United States

Authors: A Junior Scholar (i.e., PhD awarded since January, 2004)

Genre: An article, essay, or book

Publication Date: March, 2008 through February, 2010

Prize: $\$ 500$ plus travel stipend to attend 2010 HES Annual Meeting

Further Information: Contact Bruce Leslie at: bleslie@frontiernet.net 
History of Education Quarterly

University of Illinois at Urbana-Champaign

360 Education Building, MC-708

1310 South Sixth Street, Champaign, IL 61820

Phone: 217 333-2446 (Office), Fax: 217 244-7064

http://www.ed.uiuc.edu/hes/INDEX.htm

Senior Editor

James D. Anderson, University of Illinois at Urbana-Champaign

Yoon K. Pak,

Co-Editors

University of Illinois at Urbana-Chumpaign

Christopher M. Span,

University of Illinois at Urbana-Champaign

Book Review Editor

Katrina M. Sanders, University of Iowa

David Adams, Cleveland State University

Nancy Beadie, University of Washington, Seattle

Associate Editors

Timothy Cain, Univensity of Illinois at Unbana-Champaign

Kate Rousmaniere, Miami University

Eileen Tamura, University of Hawaii

Wayne Urban, University of Alabama

\section{Paul W. Mathewson Kevin Zayed}

Book Review Editorial Assistants

DeeAnn Grove, University of Iowa Michael Hevel, University of Iowa

Editorial Board

TERM EXPIRES IN 2010

Carlos Blanton,

Texas A\&M University

Benita Blessing, Obio University

James W. Fraser,

New York University

Marybeth Gasman,

University of Pennsylvania

Karen Graves, Denison University

K. Tsianina Lomawaima,

University of Arizona

Jeffrey Mirel, University of Michigan

Kathleen Weiler, Tufts University

Joy Williamson-Lott,

University of Washington, Seattle

Robert S. Wolff,

Central Connecticut State University

Roberta Wollons,

University of Massacbusetts, Boston

\section{TERM EXPIRES IN 2011}

Mona Gleason,

University of British Columbia

Joyce Goodman,

University of Winchester

Philo Hutcheson,

Georgia State University

W. Bruce Leslie, State University

of New York, Brockport

Gary McCulloch, University of London

Adah Ward Randolph,

Obio University

Alan Sadovnik,

Rutgers Unversity

Joseph Watras,

University of Dayton

The History of Education Society is an international scholarly society. Its purposes are to encourage and facilitate research in the history of education; to promote and improve the teaching of history of education; to encourage cooperation among specialists in history of education; and to promote an appreciation of the value of historical perspective in the making of educational policy. The Society is affiliated with the International Standing Conference for the History of Education, and members of the Society are automatically members of the Standing Conference.

\section{President \\ Jon Zimmerman, New York University (2010)}

\author{
Vice-President and President-Elect \\ Philo Hutcheson \\ Georgia State University (2010)
}

\section{Secretary-Treasurer \\ Robert Hampel, University of \\ Delaware (2009-2011)}

Harold Wechsler, New York University (2011)

Christine Ogren, University of Iowa (2009-2012)

Directors

Kim Tolley, Notre Dame de Namur University (2008-2010)

INDIVIDUAL MEMBERSHIP: Membership is open to all persons interested in the study of the history of education. Membership provides for subscription to the History of Education Quarterly; subscription to The Netzork, a newsletter published jointly with Division F of the American Educational Research Association; and receipt of the program of the annual meeting of the Society. Members of the Society are automatically members of the International Standing Conference for the History of Education. Membership offers subscription to publications on a calendar-year basis only. Dues are $\$ 25$ for students, $\$ 50$ for others. NonU.S. members should add \$7 to cover additional postage for surface mail; \$20 for airmail. To become a member, send a check for the appropriate amount in U.S. dollars only to Journal Customer Services, John Wiley \& Sons, 350 Main Street, Malden, MA 02148, USA, or to pay by credit card visit www.blackwellpublishing.com/journals/hoeq/members.htm

Make checks payable to John Wiley \& Sons. Indicate preferred mailing address and the calendar year in which your subscription should begin. 
Article Submissions: Manuscripts must be submitted electronically to the History of Education Quarterly manuscript submission site, http://ojs.ed.uiuc.edu/index.php/heq/index. Questions regarding submissions can be directed to the editorial staff at heg@ed.uiuc.edu. See last page of this issue or our website http://onlinelibrary.wiley.com/journal/ 10.1111 /(ISSN) 1748-5959 for guidelines on submission. The editor will only consider articles that have been submitted exclusively to the History of Education Quarterly.

Book Reviews: Assignments of reviews are made from a file of potential reviewers. To have your name added to that file, send curriculum vitae to the book review editor. Requests to review particular books cannot be honored.

HISTORY OF EDUCATION QUARTERLY, (Print ISSN: 0018-2680 Online ISSN: 1748-5959), is published quarterly on behalf of the History of Education Society in conjunction with the College of Education, the University of Illinois at Urbana-Champaign, 351 Education Building, MC-708, 1310 South Sixth St., Champaign, IL 61820 by Wiley Subscription Services, Inc., a Wiley Company, 111 River St., Hoboken, NJ 07030-5774.

Mailing: Periodical Postage Paid at Hoboken, NJ and additional offices.

Postmaster: Send all address changes to HISTORY OF EDUCATION QUARTERLY, Journal Customer Services, John Wiley \& Sons, Inc., 350 Main St., Malden, MA 02148-5020.

Publisher

History of Education Quarterly is published by Wiley Periodicals, Inc., Commerce Place, 350 Main Street, Malden, MA 02148; Telephone: 781388 8200; Fax: 7813888210

Journal Customer Services: For ordering information, claims and any inquiry concerning your journal subscription please go to www.wileycustomerhelp.com or contact your nearest office:

Americas: Email cs-journals@wiley.com; Tel: +17813888598 or 18008356770 (toll free in the USA \& Canada).

Europe, Middle East and Africa: Email: cs-journals@wiley.com; Tel: +44 (0) 1865778315.

Asia Pacific: Email: cs-journals@wiley.com; Tel: +65 65118000.

Japan: For Japanese speaking support, Email: cs-japan@wiley.com; Tel: +65 65118010 or Tel (toll free): 00531650480. Visit our Online Customer Get-Help available in 7 languages at www.wileycustomerhelp.com.

Production Editor: Grace Chen (email: HOEQ@wiley.com)

Advertising: For advertising enquiries, please email Kristin McCarthy (email: kmccarthy@wiley.com)

Information for Subscribers

History of Education Quarterly is published in 4 issues per year. Institutional subscription prices for 2010 are: Print \& Online: US\$140 (the Americas), US\$178 (Rest of World), €115 (Europe), £91 (UK). Prices are exclusive of tax. AsiaPacific GST, Canadian GST and European VAT will be applied at the appropriate rates. For more information on current tax rates, please go to www.wileyonlinelibrary.com/tax-vat. The price includes online access to the current and all online back files to January 1, 2007, where available. For other pricing options, including access information and terms and conditions, please visit www.wileyonlinelibrary.com/access.

\section{Delivery Terms and Legal Title}

Where the subscription price includes print issues and delivery is to the recipient's address, delivery terms are Delivered Duty Unpaid (DDU); the recipient is responsible for paying any import duty or taxes. Title to all issues transfers FOB our shipping point, freight prepaid. We will endeavor to fulfil claims for missing or damaged copies within six months of publication, within our reasonable discretion and subject to availability.

Back Issues: Single issues from current and recent volumes are available at the current single issue price from cs-journals@wiley.com. Earlier issues may be obtained from the Periodicals Service Company, 11 Main Street, Germantown, NY 12526, USA. Tel: +1 5185374700 , Fax: +1 5185375899 , Email: psc@periodicals.com.

\section{Copyright and Photocopying}

C 2010 History of Education Society. All rights reserved. No part of this publication may be reproduced, stored or transmitted in any form or by any means without the prior permission in writing from the copyright holder. Authorization to photocopy items for internal and personal use is granted by the copyright holder for libraries and other users registered with their local Reproduction Rights Organisation (RRO), e.g. Copyright Clearance Center (CCC), 222 Rosewood Drive, Danvers, MA 01923, USA (www.copyright.com), provided the appropriate fee is paid directly to the RRO. This consent does not extend to other kinds of copying such as copying for general distribution, for advertising or promotional purposes, for creating new collective works or for resale. Special requests should be addressed to PermissionsUK@wiley.com.

\section{Disclaimer}

The Publisher, History of Education Society, and Editors cannot be held responsible for errors or any consequences arising from the use of information contained in this journal; the views and opinions expressed do not necessarily reflect those of the Publisher, History of Education Society, and Editors, neither does the publication of advertisements constitute any endorsement by the Publisher, History of Education Society, and Editors of the products advertised.

Access to this journal is available free online within institutions in the developing world through the AGORA initiative with the FAO, the HINARI initiative with the WHO and the OARE initiative with UNEP. For information, visit www.aginternetwork.org, www.healthinternetwork.org, www.oarescience.org

View this journal online at wileyonlinelibrary.com.

Wiley's Corporate Citizenship initiative seeks to address the environmental, social, economic, and ethical challenges faced in our business and which are important to our diverse stakeholder groups. We have made a long-term commitment to standardize and improve our efforts around the world to reduce our carbon footprint. Follow our progress at www.wiley.com/go/citizenship

For submission instructions, subscription and all other information visit http://onlinelibrary.wiley.com/journal/10.1111/(ISSN)1748-5959

ISSN 0018-2680 (Print)

ISSN 1748-5959 (Online)

Printed in the USA by The Sheridan Press. 


\section{History \\ of Education \\ Quarterly}

Volume 50 • Number 4 • November 2010

\section{Contents}

\section{Articles}

429

The Word from a Walrus: Five Decades of the History of

Education Society

Wayne 7. Urban

460 "But a Step from College to the Judicial Bench": College and Curriculum in New England's "Age of Improvement"

Kenneth Nivison

488 The Heritage Fallacy: Race, Loyalty, and the First

Grambling-Southern Football Game

Thomas Aiello

513 Anticommunism and Academic Freedom: Walter C. Eells and the "Red Purge" in Occupied Japan

Ruriko Kumano

Book Reviews

Angulo, William Barton Rogers and the Idea of MIT

By Lester F. Goodchild

542 Bays and Widmer, China's Christian Colleges: Cross-Cultural Connections, 1900-1950

By Ting-Hong Wong

Boles, University Builder: Edgar Odell Lovett and the Founding of the Rice Institute

$550 \quad$ Carper and Hunt, The Praeger Handbook of Religion and Education in the United States, 2 volumes

By Bruce 7. Dierenfield

553 Danforth, The Incomplete Child: An Intellectual History of Learning Disabilities

556 Donson, Youth in the Fatherless Land: War Pedagogy, Nationalism, and Autbority in Germany, 1914-1918

By Daniela Blei 
Gasman, Envisioning Black Colleges: A History of the United Negro College Fund

By Linda M. Perkins

562 Heskel and Dyer, After the Harkness Gift: A History of Phillips Exeter Academy Since 1930

By Benjamin A. Jobnson

Macaulay, Marching in Step: Masculinity, Citizenship, and the Citadel in Post-World War II America

By Jennifer R. Green

$568 \quad$ Nielsen, Beyond the Miracle Worker: The Remarkable Life of Anne Sullivan Macy and Her Extraordinary Friendship with Helen Keller

By Penny L. Richards

$570 \quad$ Paris, Children's Nature: The Rise of the American Summer Camp

By Kevin C. Armitage

Segalla, The Moroccan Soul: French Education, Colonial

Ethnology, and Muslim Resistance, 1912-1956

By Corrie Decker

$576 \quad$ Siddle Walker with Byas, Hello Professor: A Black Principal and Professional Leadership in the Segregated South

By Hilary 7. Moss

579 Span, From Cotton Field to Schoolbouse: African American Education in Mississippi, 1862-1875

By Michael Fultz

581

Woyshner, The National PTA, Race, and Civic Engagement, 1897-1970

By Susan Levine

PHOTO CREDIT: Lawrence Cremin (1925-1990), Columbia University, Teachers College. Photo courtesy of the Columbia250 website.

http://www.c250.columbia.edu/c250_celebrates/remarkable_columbians/ lawrence_arthur_cremin.html 